\title{
Case Pending: Practices of Inclusion and Exclusion in a Class of Plaintiffs by Rita Kesselring
}

This is an Accepted Manuscript of an article published by Taylor \& Francis in Anthropology Southern Africa on 18 May 2015, available

online: https://www .tandfonline.com/doi/abs/10.1080/23323256.2015.1016053

\section{$\underline{\text { Abstract }}$}

Apartheid victims have had a difficult standing in South Africa in the years that have followed the Truth and Reconciliation Commission (TRC). In the government's perspective, the TRC had conclusively dealt with apartheid victimhood. Consequently, when victims turned to U.S. Courts in the early 2000s to sue multinational companies for their role in the perpetration of apartheid-era crimes, they faced everything from skepticism to hostility. From a different perspective, many scholars shared the skepticism, fearing the individualizing power of the law. But contrary to the TRC, the apartheid litigations, which are class actions, offer individual victims the chance to make their claims collectively.

With the help of the extended case method, the article shows how both victims and courts struggle with the difficult relationship between structural reasons, collective action and individually experienced harm. I enquire into the logics of the law as produced in courts and into lived experience of apartheid-era victimhood in today's South Africa and suggest a refinement of theories of legalization.

Keywords: law; class action; South Africa; victimhood; apartheid crimes; structural violence

Author, affiliation:

Rita Kesselring, Dr.

Senior Lecturer, Institute of Social Anthropology

University of Basel

Münsterplatz 19

4051 Basel, Switzerland

rita.kesselring@unibas.ch 


\section{Case Pending: practices of inclusion and exclusion in a class of plaintiffs}

On a cold winter day in June 2009, two women wait in a Western Cape branch of the South African Social Security Agency (SASSA), which manages and pays out social assistance grants to millions of beneficiaries. After some time, they start talking with one another. They realize they both have the same problem; they have not received the child support grants for their grandchildren for several years even though their respective daughters have officially assigned them the caretaker status. This seems to have slipped through the system or, worse, someone else has benefitted from abusing the system. It is not the first time they try to clarify the problem with the SASSA officer or to get an appointment at all, and they struggle to understand the bureaucratic processes of the grant system, and why it fails to deliver the grants they think they are eligible for.

Their conversation then moves on to the South African apartheid victims' support group Khulumani of which one of them, Ms Nala [name changed], is a member. Khulumani has so far unsuccessfully lobbied for the release of the R1billion sitting in the so-called President's Fund, which was established for the purpose of supporting victims of gross human rights violations during apartheid (Truth and Reconciliation Commission South Africa 2003, vol.6, section 2, ch.5). This may be one of the reasons why the majority of those who hear about Khulumani first put it into the same category as SASSA, a source for grant-seekers - until they learn more about the organization, its self-support character and its lack of funding. At the moment at hand, the other woman rather typically wants to know more about Khulumani and how to become part of it. But when Ms Nala and I drive home, she tells me: "She is not a real victim. She knows nothing about the Crossroads Fire and 1986."

Why is it still an issue for two elderly women who share the same situation in the new South Africa who is and who is not an apartheid victim - almost two decades after the end of apartheid, more than a decade after the TRC finished its work and another decade after the Commission handed over its final report and recommendations to then President Thabo Mbeki? If one has been following the political and legal happenings in relation to apartheid-era victimhood in the past decade, the answer seems straightforward. Seven years before the conversation above took place, in 2002, Khulumani had filed a class action suit in U.S. Courts, the so-called apartheid litigations, in which they allege that multinational companies had aided and abetted the security forces of the apartheid regime in its perpetuation of crimes. As the case 
is still pending, Ms Nala is looking for new members for Khulumani with whom to share the legacy of experiences of harm and to see Khulumani grow. Becoming a Khulumani member is equated with becoming a plaintiff in the lawsuit and hence a potential beneficiary if the case gets settled or damages are being paid out. Ms Nala, a very active member, identifies potential members to the best of her knowledge - which is embedded in a very local context. In the wider Cape Town area, some of the most important structural violations took place in the 1970s and 1980s when thousands of informal residents lost their belongings and often several family members during raids by the police and their undercover helpers from the communities, the 'witdoeks'. Ms Nala's notion of who a victim is relates to her own experiences during that time.

In other words, while the TRC was thought to end claims to victimhood, the pending apartheid litigations keep alive an environment in which it matters whether one is acknowledged as a victim or not. This could be the reading by scholars who are critical of processes of 'legalization' (Blichner and Molander 2008). Current legal anthropology in particular is concerned with processes of legalization, that is the discursive reduction of subjectivities of those who turn to the courts with their social concerns (Comaroff and Comaroff 2006; 2007). Turning to the law, they argue, does not solve the social problems from which legal cases emerge. On the contrary, legal cases may help create legalized subjectivities and thereby again subject people to externally produced discourses (Comaroff and Comaroff 2003; 2006; 2007; Robins 2009; Van Marle 2008).

I believe that, in this discussion, the discursive dimension of the "force of the law" (Bourdieu 1986) has been overemphasized. This has made it difficult to discuss the effects of legal discourse onto the social domain: too strong a focus on discourses alone conceals the societal underpinnings that give the law the ground to be effective. Bringing social practice back in, I suggest a refinement of the theory of legalization by paying close attention not only to discursive formation but also lived experience in a particular context. Every norm needs to encounter societal realities in order to become effective in shaping sociability (Popitz 2006). Norms such as legal norms may help producing their own certainties, but they do not have agency by themselves (cf. Bourdieu 1986). 
One consequence of processes of legalization has been very prominently criticised in scholarly writing: the tendency of the law to break up a collective. As Jean and John Comaroff write, various rights discourses, including human rights, advocate a language of individual rights (2003:466) and thereby promote an "idiom that individuates the citizen" (2003:457). The law produces shifts in how people relate their individual personhood to a collective; it jeopardises their solidarity with and similarity to others. I will show that this tension between the individual and the collective is not only a feature of the law but also of post-apartheid South Africa in relation to enduring apartheid injuries. The relation between victimhood and the law is shaped by the fact that structural injuries have both an individual and a collective dimension.

Conceptually, I speak of victimhood as a state of being of a victim of human rights violations. This state is self-ascribed and a genuinely intimate and personal experience. Victimhood is often not expressed in a discursive form. Once a person takes his or her victimhood into the predicative realm, I speak of victim subjectivity. Subjectivity is necessarily discursively formed and it is in a relation to other predicated forms of victimhood. Victim subjectivities thus refer to what I call victims' subject positions. These are discourses - often dominant, such as the law - which give ideas and ideals of what a victim is or is supposed to be. These three different positions are empirically not clear-cut. Moreover, they are not exclusive: a person's self is "the location of multiple and potentially contradictory subjectivities, each established within discourses and discursive practices" (Merry 2003, 349).

Read along this conceptual framework, my argument is as follows. The lived experience of victimhood gives the law (a dominant discourse) the opportunity to become effective; it shapes people's being-in-the-world and their positions vis-à-vis others. It is hence not the law that produces legal subjectivities. As I will show, apartheid victimhood as an ongoing lived experience today has not been addressed sufficiently for people not to claim their victimhood when the opportunity arises. In the process of engaging their victimhood with discourses, though, the forms of sociality they live change.

Using a hearing of the apartheid litigations before the Southern District Court of New York, the first part of the article analyses how a court grapples with notions of collectivity and 
individuality. In the second part of the article, I show how the notions of collectivity and individuality negotiated in court are effective in the social domain by looking at one testimony by a plaintiff on an ordinary afternoon in South Africa. In the final part, I make a more general argument on the efficacy of the law. I highlight the kinds of including and excluding practices during the time legal cases are pending before courts, i.e. when the law is 'inactive'. While much attention is given to the outcome of prominent court actions, I try to think through what fairness may be for plaintiffs in relation to pending legal cases.

For this analysis of law and its societal effects (Goodale and Merry 2007; Griffiths, BendaBeckmann, and Benda-Beckmann 2005; Nader 2002), I use sources and methods that legal anthropology has long applied. I combine the analysis of court records with long-term participant observation; I shared the everyday lives of plaintiffs over 19 months of field research between 2009 and 2013. During this time, I tried to understand how they relate their experiences to the logic of the law and how the law in turn shapes their subjectivities (Conley and O'Barr 1990; Merry 1990).

\section{The Legal Discourse: "I really don't know what it was to be a claimant in South Africa"}

Khulumani is a membership organization of roughly 70'000 members. It organizes many mundane and day-to-day activities, but it is also involved in class actions against companies both in U.S. and in South African Courts. Khulumani lodged the complaint Balintulo v. Daimler $A G$ in U.S. Courts against multinational companies. The case was later consolidated with a second apartheid litigation, Lungisile Ntsebeza et al. vs Daimler Chrysler Corporation et al. The claimants sue (initially more than 50 now reduced to Ford and IBM) companies for their alleged aiding and abetting the security forces of the apartheid regime in the commissioning of human rights abuses. The cases are filed under the Alien Tort Statute (ATS), a highly contested Act of the U.S. Constitution, which gives non-US citizens the right to sue in U.S. Federal Courts over violations of international law, whether they arose in the United States or abroad.

\footnotetext{
' In April 2013, the U.S. Supreme Court ruled in Kiobel v. Royal Dutch Petroleum Co. against the extraterritorial application of the Act. Judge Scheindlin of the Southern District of New York granted plaintiffs of the apartheid litigations the motion for corporations to be held liable under the ATS but excluded non-U.S. companies (leaving IBM and Ford). The U.S. lawyers filed an updated complaint, which on August 29, 2014 the Judge dismissed on the grounds that the plaintiffs had not shown sufficient connection with the U.S. At the time of submission, the U.S. lawyers were planning to file an appeal.
} 
On February 26 2009, Judge Shira Scheindlin heard the two consolidated apartheid litigations before the Southern District Court of New York.' She considered oral arguments from both defendants and plaintiffs. The purpose of the hearing was her consideration of the defendants' motion for the claims to be dismissed. This motion was a reaction to the amended claims filed

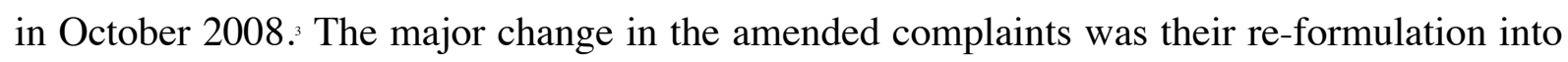
class actions suits. At the time of the hearing, the Judge had not certified the classes. The proposed classes consisted of groups of individuals who have suffered a common injury (extrajudicial killing, torture, detention and cruel treatment). ${ }^{4}$

The apartheid litigations are about the liability of corporations in the perpetration of gross human rights violations. Unlike in parts of the international criminal justice system where victims are primarily reduced to witnesses and are not granted plaintiff status, ${ }^{5}$ these civil cases rely on their testimony for the compilation of the complaints and on their victim status for the institution of the lawsuits. As we will see, the plaintiffs are a source for argumentation even in procedural questions for the attorneys of both sides.

In the two hours hearing, the term 'plaintiffs' generally consolidated the plaintiffs and the plaintiffs' attorneys. There was no distinction between the individuals alleging violations and the persons who act on their behalf in court. This (usual) way of semantically consolidating plaintiffs and their attorneys may explain the fact that plaintiffs themselves found little attention in the hearing as persons. Also, plaintiffs were mostly considered as a large group of persons, as a collective, indistinguishable. Since class certification was not an issue in this particular hearing, the question how the collective relates to the individual case or, how the law can get a grasp on the triangle perpetrator-action-victim did not play a major role. Only once, in a revealing moment, the Judge asked the plaintiff's attorney to break down the general allegations to an individual case. She asked Mr. Hoffmann, attorney for the Ntsebeza plaintiffs, to show how the complaints allege Barclays to have committed a tort that goes beyond mere work

\footnotetext{
Southern District Reporters provided the transcript of the hearing. The author holds a copy of it.

"Amended Complaint for Docket MDL No.02-md-1499 (JES); Jury Trial Demanded, Class Action. Upon the hearing, Judge Scheindlin issued her order of April 8, 2009, which allowed the cases to go forward under the condition that changes according to her order were made.

‘ Torture includes rape. South African security forces between 1960 and 1994 allegedly executed all violations.

s This counts for the International Criminal Tribunal for Rwanda and the International Criminal Tribunal for the Former Yugoslavia but not for the International Criminal Court where victims' legal representatives are parties to the trial.
} 
discrimination. When he remained rather vague, the Judge pressed him to show precisely how Barclays engaged in torts.

Mr. Hoffmann: In particular, the one plaintiff that we have with respect to Barclays suffered gross discrimination and was forced to work, could not work in certain places that were considered to be white areas and was forced to go to Bantustans and to work outside of that. That is the nub of that particular claim. We also named that Barclays did worse things to the work force as a whole, but that is what the particular plaintiff suffered. (p.49: 3-10)

This shows that even in class actions where collective injuries are alleged, the Court needs an individual touchstone to test generalized harm. Typically, these individual cases each represent (often thousands of) similarly situated persons who make up the classes. The class representatives are treated like individual cases. In other words, if this individualization of harm fails, i.e. when the plaintiffs cannot prove the link between perpetrator, action and victim exemplarily, the defendant companies can argue that the complaint is not consistent. Furthermore, individualization of harm can be a way of contesting commonality among class members. The "missing glue" among class members, as Supreme Court Judge Scalia formulates it in a decision ${ }^{6}$, can then be an argument for a case to be dismissed.

Towards the end of the hearing, there were two instances where the consolidation between plaintiffs and plaintiffs' attorneys collapsed, as a consequence of which the Judge obtained some albeit minor insights into victims' personhood. Mr. Barron, attorney for the defendant companies, asked for permission to raise a topic of concern: the consideration of adjudicating the litigations for practical reasons, given the "huge and amorphous nature of this case" (p.80: 13) and "the distance of those events [injuries committed by the apartheid regime] from our shores, 8,000 miles" (p.80: 17-18). He continued by pressing the Court to consider

the impossibility of doing reasonable discovery, the volume of materials that this Court would have to review, and keep in mind that each of the plaintiffs, of which there are

- U.S. Supreme Court's 2011 decision in Dukes v. Wal-Mart www.supremecourt.gov/opinions/10pdf/10-277.pdf (accessed January 22, 2015) 
many, and each of the punitive members of the class would have his own individual story, or her own individual story, taking place at different times in different place in South Africa with different witnesses, different facts. (p.80: 18-25)

In U.S. civil law, discovery is a pre-trial phase in which each side requests various forms of evidence from the other side. In the cases discussed here, this means the plaintiffs' attorneys would, for the first time, have access to the companies' archives and that the defendants' attorneys could request any kind of evidence from the plaintiffs' side.

Mr. Barron referred to the high number of potential plaintiffs in order to argue for dismissal of the claims. He referred to the complexity of individual lives and violations all packed into one class action suit. To do so, he unveiled the plaintiffs in their individuality, however limited. Willingly or not, Mr. Barron added a perspective that had been totally absent up to this stage of the hearing. When his turn came, Mr. Hoffman, plaintiffs' attorney in the second apartheid litigation, drew on the plaintiffs' visibility as partly established by the other party.

The thing is even if the court didn't certify the class, there are people with real claims in front of the Court that have come forward and deserve to have their rights adjudicated. (p.99: 3-6)

Mr. Hoffman pointed out the fact that the dismissal of the case would not resolve problems or silence claims. He attempted to bring the plaintiffs into the Judge's reality by visualizing their personhoods as 'in front of the Court'. He brought them - rhetorically - across the Atlantic and from the Southern to the Northern hemisphere. Hence, for the plaintiffs' attorneys, plaintiffs' individuality in their numbers served as a plea for recognition and attention.

There is another instance in which the plaintiffs were granted recognition as actors. One of the defendants' attorneys, Mr. Greenwald, referred to a principle of limitation, the time bar: "Just to state the obvious, this case concerns events that occurred 15, 20, 30 years ago" (p.86: 5-6). He argued that the cases had not been brought within ten years after the end of apartheid and had therefore been filed too late. 
There is a distinct difference between when Mandela was elected and when apartheid ended. Indeed, it was so distinct that in 1991, the first President Bush lifted the sanctions that President Reagan had imposed under the CAAA [Comprehensive Anti-Apartheid Act] (p.88: 21-24).

As the apartheid litigations were first filed in 2002, the defendants argued that they were not filed within ten years after what was, according to their reading of history, the end of apartheid. This claim provoked the Judge to ponder about plaintiffs' lived realities in the early 1990s. In her response, she very explicitly talked about the life-worlds of the plaintiffs:

The fact that our [US] government became comfortable enough to lift restrictions doesn't tell me what it was like to be a black person living in South Africa in 1991 who was contemplating suing some South African companies or subsidiaries of national companies that do business in South Africa claiming that they were collaborating in the apartheid system when the control was still in the hands of the very white politicians who had enforced the system. So there is a disconnect here between our government lifting a restriction on certain things and what it would have been like to be a plaintiff. (p.89: 4-14)

The Judge refused to assume correlation between a foreign policy move by the then U.S. administration and the lived reality of black South Africans between Mandela's release and the first democratic elections. For the attorney, this was a "highly questionable historical assumption" (p.89: 18) and he reverted to his second trump card. He insisted that the concept of "equitable tolling" nonetheless applied. In other words, the Judge summarized for him, "what did they do for eight years". Even if it fell within the ten years, there was only so much time plaintiffs should need to file a suit. This left the Judge pensive:

Can I begin to explore when is the timing for when they could have brought the action, whether it's '90 or '94, would that not take some discovery. Because I really don't know 
what it was to be a claimant in South Africa during those four years. (p.93: 24 - p.94: 3)

The attorney insisted, 'we have eight years of doing nothing. More if you go by our reading of the history' (p.94: 13-14). Mr. Hausfeld, attorney in the Khulumani case, was later asked to take a stance on "why is '94 the trigger date?" (The Court; p.101: 4). He replied that that year was the "first practical time when South African had its own government not associated with apartheid" (p.101: 5-6). In the early 1990s, everything was still instituted by a white South African government (p.101: 16-17). The Judge pushed to the "eight years of doing nothing" question. Mr. Hausfeld vaguely mentioned the context the country was in, there were "innumerable issues and challenges" (p.102: 23-24). The Judge was quick to tell him what his argument should be: "Maybe the better answer is the TRC process" (p.103: 2-3) and added “[s]o now I'm the judge and the lawyer" (p.103: 6). Mr. Hausfeld was about to get to that and emphasized that the TRC process was only finished in 2003 when the final report was issued.

Both legal parties were cautious not to emphasize the aspect of lived experience too strongly, despite the Judge's insistence to get to the sensation of what it meant to live in South Africa in the 1990. She left the hearing with little new knowledge of the slowly growing global awareness of corporate accountability in the mid and late 1990s. She also heard little about what it meant and means politically for South Africans to stand up as a 'victim' of human rights violation in the context of the Mbeki administration. The hearing tells us little about the slow formation of a victims' support group organization across the country and the formation of a victims' subject position in the times of the TRC and its aftermath (Kesselring 2012a; Kesselring 2012b).

Generally, the notion of the individual plaintiff as a person is strikingly absent in the hearing. I pointed out three exceptional moments. In the first instance, one of the plaintiffs' attorneys is requested to showcase the type of violation with the help of one representative case, thus individualizing injury to comply with the legal logic. In the second and third instances, the attorneys briefly disintegrate the notion of a collective (a class) into individual plaintiffs. It is a shift from the general to the individual. 
Judging on this transcript and on many similar court proceedings, even if the applicants have to prove injury on an individualized basis and individuality is an argument for the unmanageability of big class actions, class actions do neither further the visibility of the individual plaintiffs nor the recognition of their experiencing personhood. An astute judge may make a difference by inquiring into the plaintiffs' lifeworlds - as a collective or as individuals; but the general procedure does not allow for it nor are attorneys particularly prepared to deliver such information.

\section{How is it like to be a claimant in South Africa?}

The massive attention for apartheid-era victimhood during the working of the TRC was followed by striking inattention and even disregard of many un-heard experiences under apartheid rule and their legacies through the 20 years after the official end of apartheid. Much hope was put into the TRC process. Victims and victims' organization had waited until 2003 for all seven volumes of the final report to be published. Just as Judge Scheindlin argued, the hope attached to the TRC process prevented civil society to take legal action against companies and the new government. As long as the government had not announced which of the TRC's recommendations it intended to adopt and which ones to ignore, there was little reason to go to the courts. The hope that a new democratic government would redress the past decidedly, even if with huge delays, I believe, was coupled with a level of exhaustion among activists. Also, given the fact that many activists were recruited into government positions, a critical group of activists and victims first had to form and to develop shared ideas and strategies. Today, apartheid victims live in an ambivalent and fluctuant environment. Success follows failure; a sudden surge of publicity in TV or newspapers (often in relation to the apartheid litigations) follows several months of little coverage of their concerns.

When victims finally decided to turn to U.S. courts, one major reason was dissatisfaction with the TRC process in that it only dealt with experiences of violence on an individual basis. Paradoxically enough, the TRC and the U.S. Courts adopt a similar albeit slightly different approach to the issue of individual versus collective victimhood. The TRC individualized injuries by limiting the scope of its work to gross human rights violations exclusively, and by selecting only several thousands of cases. By way of this limitation and selection, it hoped to trigger a broader process of vicarious healing and reconciliation. This hope did not materialize 
for thousands of victims who struggle to move on. They have to deal with their embodied and in most cases unacknowledged victimhood on an everyday basis. Even if the general or vicarious attention is important, injuries, as I will show below, have a nonnegotiable individual core, which needs to be addressed somehow. Hence, it is not only the law that grapples with the relation between collective and individual injuries, but also victims themselves.

Against this background, plaintiffs see class actions as a way to avoid personalizing harm which they feel they suffered collectively. Class actions offer the opportunity to make structural violations actionable. Not each injury to every harmed person has to be alleged in separate cases; the class comprises those harmed in similar ways by the same agents. Class actions can thus point to a social and political context in which plaintiffs want to strengthen similarities among themselves and present their injuries in a united manner. The whole notion of a class then rests on the idea of shared injustices - much more than just similar injustices.

The apartheid litigations, as long as they are pending, accommodate different kinds of victims and experiences - not because the U.S. law is so flexible, but because for the first 13 years, no class of victims has been certified, and nobody has explicitly been included or excluded. It is in this context that the effects of class actions on the social realm are interesting to examine. Does the (attempt of) individualisation of harm (as fleshed out in the court hearing above) become socially relevant as legalization theory suggests? Do plaintiffs expose themselves to processes that break apart their practiced solidarity by turning to the courts seeking recognition for the generalized nature of apartheid-era violations?

\section{Trapped Between Victimhood and its Articulation}

To answer these questions, I turn to a situation where a Khulumani member testified to her injuries in a more or less ordinary social setting in Philippi Township, Western Cape, South Africa. I show how she, who has fallen victim to crimes just as thousands of others, seemed to feel the necessity to give evidence to her individual victimhood by singling out herself. Given the fluctuant attention politics gives to victims' concern, social situations in which victims can attempt to speak from their embodied knowledge and "try on" (Merry 2003) their political victim status are rare, and they come with uncertainty whether or not they will be heard or understood. As a result of this unreliable environment, victims are irrevocably trapped between 
their sentient victimhood, which they do not necessarily want to share, and the urge to articulate their victimhood. A legal understanding of victimhood offers one manner of articulation.

Ms Beauty Notle Kotta is in her 60s and is the head of a household of six persons: her son and her daughter, a mother of three children. They live in extremely poor conditions in a two-room RDP house. Ms Kotta's family comes from Komga in the former homeland Transkei. On that afternoon in 2009, she spoke about the fires in the 1980s in the Cape Flats, which resulted in the death of her son. Our conversation took place in the presence of two women who can broadly tell the same story. I was known in certain communities by that stage of my research and Ms Kotta had literally commanded me to come and visit her in her house. Since I did not sufficiently understand isiXhosa, she told me about the destruction of the settlement in rough, but very powerful English:

You believe, you can see the head of people throw away there. The bodies here. The head is there. Sometimes you see the leg. Sometimes you see the... True, man! Was very bad. Frightened. If you go, you see, this is a person. They didn't bury [him/her]. The head of people, the head of people, the legs, the body. Other people, the one they saw, we saw, was burning out. You can't see who is this. Burning out! Black!! You see the legs there. You don't know who is this. [...]. It was not nice, very bad... We're running, we're running.

She also spoke about how she tried to save some belongings:

Monica [my daughter] [...] was five years of age. [...] I went there to try, I must get my things inside. I saw at that time, it was afternoon like this... I go little bit, I must get some things. [...] When I went there, it was late, it was late like sometime seven o'clock in the evening. I try to take my things. They come, these men, I think - like next door. [...] I run. I run with my child I put on my back. I don't know who is the other children in the fight there, the boys. [...] We didn't buried, put away there. We have no time. If you go there, the people they can kill you. They kill you. They don't mind. [...] Otherwise you going to death. We running, we running. 
And then she turned to her son's death:

Was burning there. And the Boer was take the dog, close, can't get out. Was burning there. They didn't buried. And too, my son, too, my son. I had two sons. But I have one son now. I had two sons.

Before I left her house, she looked for an old piece of paper and showed it to me: "You see, I have two witnesses, you see. I have their ID numbers. They know what happened, they were there." Beauty Notle Kotta was not present herself when her son passed away in 1986. He burned to death in the informal settlement Nyanga Bush, a township at the outskirt of Cape Town, when the residents were forcibly removed as part of the 'clean-up' of the Crossroads Complex and KTC, a mushrooming and informal settlement which was considered a national 'security threat' by the State Security Council (Cole 2012, 188ff.). The 12-years old boy did not survive the attacks of the security and military structures of the apartheid regime (and collaborators). Ms Kotta's second son Laurence fled to the Zolani Centre in Nyanga, in which hundreds of others who were dispossessed and displaced over night hoped to find shelter from the destructive forces, together with other estimated 20.000 to 30.000 'refugees'. At the time of our meeting, he still lived with his mother in Philippi, a settlement just across the road from the Nyanga Bush settlement. In Philippi, many people built provisional shelters in what was then bush and forest. Most of them resisted the planned removals of the mid-1980s to the township Khayelitsha which is much further away from the central city. During my visit, Laurence seemed restless and absent and did not join us. "My son was frightened. Not right in there [in his mind] since he saw...he saw... He got a picture [of the fires of 1986], you know."

In Ms Kotta's monologue, both the collective and the individual dimension of injuries were manifest.' On the one hand, Ms Kotta spoke of the 'us'-dimension ("events as they happened to "us"”; Jackson 2004, 71). Many parts of her testimony referred to shared suffering. In the raiding of the settlements and in the fights between the security forces, their "helpers" from the

' In April 2013, two years after the conversation I am relating here, her son passed away unexpectedly, which left Ms Kotta deeply shocked.

- The testimony bears traces of prior coaching as to how to communicate her experiences. In 2003, Ms Kotta participated in a memory and healing project run by the Human Rights Media Centre and Khulumani Western Cape called Breaking the Silence: A Luta Continua. The project entailed the drawing of so called body maps which were shown in several exhibition places in South Africa and abroad. 
communities, the so-called 'witdoeks', and the community members whose leaders were organised in gangs, women and children were often not singled out as targets of violence, but became targets nonetheless (Cole 1987). The loss of lives, belongings and housing were often part of a broader strategy to frighten communities and demonstrate power. This collective dimension of injuries and testifying to it relates to the ways people testified in front of the TRC. While the TRC had invited only specific individual testimonies, the tension between testifying to an individual and collective element of crime existed in the TRC process, too. While persons had to prove their individual victimhood, they testified to a more broader context, too precisely because this broader context was not examined by the TRC (Bonner and Nieftagodien 2003; Derrida 2002; Harries 2010). As a result, victims came to testify with a double subjectivity: as individual victims and as part of a more structural group of victims.

While the 'us-dimension' was highly present in Ms Kotta's testimony, she also singles herself out when she refers to specific instances. These are experiences of pain she has to cope with herself and experiences which do not necessarily socialize. By the same token, they are also instances that she can claim as specific violations that happened against her person. Part of this individual dimension of victim subjectivity was the instance when Ms Kotta produced some evidence which she might not include in an everyday account: a piece of paper with ID numbers of two persons who she said eye-witnessed the death of her son. This is both a kind of a written record and the referral to the words of others that should serve as objective external testimony to the violations. She produced this evidence in a non-legal setting, but in a situation which she thought of as conducive for her grief and claims be heard. I came to represent a person who wanted evidence even if I never asked her to talk about her experiences; something I deliberately avoided out of both delicacy and fear of re-traumatisation. Evidence, of course, is one of the major aspects of what constitutes legal claim making. Being able to produce evidence should convey the status of a victim in the realm of the law. Of course, Ms. Kotta's prime interest was not to conform to a legalized discourse, but to relate her experiences in a manner legible to me, who did not share her experiences. In order to do so, she had to differentiate between the us-dimension of generalized suffering and her specific experiences: experiences that she could claim as wrongs committed against her own person.

In other words, in order to be legible as a victim, she felt she had to differentiate her own experiences from those of the others. This is a striking analogy to the law's logic in relation to 
class actions. While principally, the law allows classes to allege collective injuries, it nonetheless has to grasp victimhood on the individual level in order to prove the causal link between perpetrator-action-victim. In this social situation at-hand, it was not first-hand experience with the law that produced the individual victim subjectivity. Ms Kotta's evidentiary-based testimony has been produced in a specific activist political environment that has turned the law into an important point of reference to prove one's victimhood (cf. Colvin 2004). In such an environment, situations of contact are not neutral, and legal and political discourses influence the assumptions people have about listeners' expectations.

It is in this light that I read Ms Kotta's testimony: she referred to the legal logic and, by necessity, had to individualize her victimhood from others'. The moment of shared memories of suffering produced new sociability between her and her listeners, but simultaneously, the need to articulate her individual victim subjectivity resulted in an individualized subjectivity. It is the legal logic played out in a highly mediated political and societal environment that resulted in a (momentous) legalization of her personhood. With Bourdieu's term (1986), the "force of law" can only become effective under specific political and social conditions. Even if the law is inactive, i.e. when cases are simply pending before one or the other court, social processes that are related to the legal claim-making nonetheless happen. They happen because specific social and political conditions are conducive for the legal logic to take effect.

\section{What is fairer, individual or collective justice?}

The law individualizes injuries for pragmatic reasons and for reasons of tradition. It has always tried to causally connect an act of harm to an agent and to a victim; and it struggles to do the same for more structural violations where these causalities are not as clear-cut. As argued above, defendant companies in class litigations often argue for the individualization of harm as one way of contesting commonality among class members. They claim "the right to present rebuttal evidence [...] with respect to every member of the class" (Lahav 2010, 119). For obvious reasons, it is too time-consuming to hold individual hearings for thousands of potential class members. Such an argument would not only demonstrate the unmanageability of the case and quicken its dismissal. Furthermore, if individual harm could not be proven for every member of the class, the class itself would appear as a misguided generalization. 
However, individualization is not only a strategy to have cases dismissed, it also speaks to a notion of supposed fairness for plaintiffs. Indeed, in relation to mass tort cases, legal scholars increasingly advocate the procedure of 'sampling' where samples of cases are tried and the resulting damages are then applied to the remaining class members (Lahav 2010; Saks and Blanck 1992). As a compromise for both defendants and plaintiffs, Alexandra Lahav, a legal scholar, suggests to consider the variation among class members. She suggests that courts hold a series of "informational bellwether hearings" $(2010,123)$ by selecting a random sample of plaintiffs and hold hearings in each of the sample cases. This statistical adjudication would reveal whether the defendant would be capable of introducing credible rebuttal evidence in relation to each of the individuals. The court could then extrapolate the result of the sample hearings to the entire class $(2010,123 \mathrm{ff}$.). Crucially, for Lahav, this would also solve what she sees as a general fairness problem for the plaintiffs in a class action: some injuries are more severe than others but conventionally all the plaintiffs receive the same pro rata amount. Working with sampling, however, the strongest cases would receive the highest awards. As she writes: "similarly situated plaintiffs will in fact be treated equally" $(2010,124)$. Determining the variation among class members should thus be advantageous not only for the courts to get a grasp on the class but also for the plaintiffs who are generally discriminated against as a result of lumping their situations together by way of consolidation..$^{10}$

For Lahav, the consolidation into a class is an unfortunate procedural move which, at least, allows us to address injustice on a grand scale. Her prime focus is on the outcome of a case, on the amount of damage, payback or relief the individual class member receives. Her approach is pragmatic and victim-centered, but it does not resolve the fundamental tension between individuality and collectivity. Sampling (which heavily draws on quantitative social sciences methodology, cf. Walker and Monahan 2002) simply replicates a system of individualization. It is important to see the premise of such suggestions. It presumes that personalized justice is, per se, fairer. This might seem self-evident to lawyers, but it may not be the view of victims.

For victims, class actions emerge out of a concern for something they share and which they want to make actionable as a group rather than as individuals. Often, individuals are happy to

\footnotetext{
${ }^{10}$ This has only been tried once in a human rights/ATS case: Hilao v. Estate of Marcos (103 F.3d 767 (9 ${ }^{\text {th }}$ Cir. 1996)). The $9^{\text {in }}$ Circuit Court approved a sampling procedure, the findings of which were presented to the jury. The case was brought under the ATS and was an opt-in class action.
} 
step back and be submerged into a class; also many victims are too weak to step up for their individual cause. Finally, filing a case requires considerable legal knowledge and connections to engage with the world of law, neither of which structurally disadvantaged individuals necessarily have. The class thus stands for something shared and the leading role is often deliberately and voluntarily delegated to a lawyer or to some victims particularly equipped to represent the similarly situated others.

This means that in the context of the plaintiffs, 'fairness' cannot be understood in terms of the monetary outcome of a case exclusively (leaving aside the fact that the majority of human rights class actions are either dismissed or settled out of court anyway, cf. Nagareda 2008) but we need to see it in its relation to lived socialities among people who share experiences. Furthermore, one has to consider that class actions are often pending in courts for a decade or longer, and are often accompanied by civil society activities such as self-help or advocacy groups and fierce contestations by their own or other foreign governments. Court cases can also be the context within which plaintiffs create new forms of socialities among themselves and develop political subjectivities (Kesselring 2012b). In such situations, measuring injuries along a statistical logic likely further threatens a collective notion of victimhood.

I do not suggest that during the years when court cases are pending, the tension between individual and collective victimhood does not play out; quite the contrary. For one, people have to stick up for their recognition in a political environment that works like a spotlight and offers attention on and off. The inattention for the injuries victims experienced means that they feel the necessity to force attention through whichever avenue they can get. For victims, their experiences of harm and their embodied knowledge of injustice are nonnegotiable. For Ms Kotta and many others, giving testimony comes with considerable effort. It involves their personhood and their sentient memories of injury. Secondly, individual victimhood is an issue because pain and the memory of past injuries have a defining individual component to it (cf. Scarry 1985) which is difficult to share discursively (Kesselring 2012b) and which continuously disrupts one's life. Notably, in both instances (political environment and embodiment of experiences of harm), it is not the law that produces individualization of victimhood. Instead, the law offers a discursive form to articulate the individual dimension of victimhood, which goes back to the nature of apartheid crimes. 


\section{Conclusion: Politics' Inattention and the Law's Inactivity}

In conclusion, I come back to the vignette with Ms Nala at the outset of the article and the question of who is a real victim and who is not. We may read these including and excluding practices as legalization. Indeed, the creation of 'the individual victim' out of a collective is one consequence of what the Comaroffs identify as a 'culture of legality'. This reading ascribes agency to the law and argues on a largely discursive level. The view that the law "has the capacity [...] to carve concrete realities out of fragile fictions" (Comaroff and Comaroff 2003, 457) does not take into account that the law needs to encounter certain 'pre-existing structures', that is underlying societal issues, in order to be effective as a discourse (Bourdieu 1986).

I tried to show that that legal subjectivities do not emerge from 'fictions' but from lived experience of injustice. In other words, what is being experienced as injustice and has remained unaddressed for too long will necessarily become an issue - notwithstanding the trigger that offers a form of articulation. If victims feel the necessity to individualize their victimhood in particular moments (of despair or for political reasons), the law offers a discursive form for this individualization. As long as the courts have not resolved the procedural questions, the law leaves the mechanisms of identifying class member to victims themselves. Any South Africa is potentially a plaintiff and, necessarily, processes of inclusion and exclusion are taking place. These practices, however, are not anchored in the law's tendency to individualize or legalize victimhood. They are anchored in the inattention of politics in matters apartheid victimhood and in the inactivity of the law.

The ways a social class of victims practice their solidarity during the years the case is pending in court and the ways they handle the real threat to that solidarity defines the possibilities for emancipation from victimhood in the long run. As emancipation from victimhood is a social process, a class ought to remain intact for it to be a possibility. The law is a means and a reference in that struggle - and not the key determinant for lived forms of sociality. 


\section{References}

Blichner, Lars Chr., and Anders Molander. 2008. 'Mapping Juridification'. European Law Journal 14 (1): $36-54$.

Bonner, Philip, and Noor Nieftagodien. 2003. 'The Truth and Reconciliation Commission and the Pursuit of "Social Truth": The Case of Kathorus'. In Commissioning the Past: Understanding South Africa's Truth and Reconciliation Commission, edited by Deborah Posel and Graeme Simpson, 173203. Johannesburg: Wits University Press.

Bourdieu, Pierre. 1986. 'The Force of Law: Toward a Sociology of the Juridical Field'. The Hastings Law Journal 38: 814-55.

Cole, Josette. 1987. Crossroads: The Politics of Reform and Repression 1976-1986. Johannesburg: Ravan Press.

_ 2012. Behind and Beyond the Eiselen Line. Cape Town: St. George's Cathedral Crypt Memory and Witness Centre.

Colvin, Christopher. 2004. 'Performing the Signs of Injury: Critical Perspectives on Traumatic Storytelling after Apartheid'. Unpublished PhD Dissertation, Charlottesville, VA: University of Virginia.

Comaroff, Jean, and John L. Comaroff. 2003. 'Reflections on Liberalism, Policulturalism, and IDOlogy: Citizenship and Difference in South Africa'. Social Identities 9 (4): 445-74.

— 2006. 'Law and Disorder in the Postcolony: An Introduction'. In Law and Disorder in the Postcolony, 1-56. London: University of Chicago Press.

—_ 2007. 'Law and Disorder in the Postcolony'. Social Anthropology 15 (2): 133-52.

Conley, John M., and William M. O’Barr. 1990. Rules versus Relationships: The Ethnography of Legal Discourse. Chicago: University Of Chicago Press.

Derrida, Jacques. 2002. 'Archive Fever in South Africa'. In Refiguring the Archive, edited by Carolyn Hamilton. Cape Town: David Philip Publishers.

Goodale, Mark, and Sally Engle Merry, eds. 2007. The Practice of Human Rights: Tracking Law Between the Global and the Local. Cambridge: Cambridge University Press.

Griffiths, Anne, Keebet von Benda-Beckmann, and Franz von Benda-Beckmann, eds. 2005. Mobile People, Mobile Law: Expanding Legal Relations in a Contracting World. Burlington: Ashgate Publishing.

Harries, Patrick. 2010. 'From Public History to Private Enterprise: The Politics of Memory in the New South Africa'. In Historical Memory in Africa: Dealing With the Past, Reaching for the Future in an Intercultural Context, edited by Mamadou Diawara, Bernard C. Lategan, and Jörn Rüsen, 121-44. New 
York: Berghahn Books.

Jackson, Michael. 2004. In Sierra Leone. Durham and London: Duke University Press.

Kesselring, Rita. 2012a. 'Corporate Apartheid-Era Human Rights Violations Before U.S. Courts: Political and Legal Controversies Around Victimhood in Today's South Africa'. Stichproben: Vienna Journal of African Studies, Human Rights in Africa, 23.

—_ 2012b. 'The Formation of a Victims' Subject Position in Today's South Africa: Embodiment and Juridification of Apartheid-Era Violence'. Unpublished PhD Dissertation, Basel: Institute of Social Anthropology, University of Basel.

Lahav, Alexandra D. 2010. 'The Curse of Bigness and the Optimal Size of Class Actions'. Vanderbilt Law Review En Banc 63: 117-31.

Merry, Sally Engle. 1990. Getting Justice and Getting Even: Legal Consciousness among WorkingClass Americans. Language and Legal Discourse Series. Chicago: University Of Chicago Press.

— 2003. 'Rights Talk and the Experience of Law: Implementing Women's Human Rights to Protection from Violence'. Human Rights Quarterly 25 (2): 343-81. doi:10.1353/hrq.2003.0020.

Nader, Laura. 2002. The Life of the Law: Anthropological Projects. London: University of California Press.

Nagareda, Richard A. 2008. Mass Torts in a World of Settlement. Chicago: University of Chicago Press. Popitz, Heinrich. 2006. Soziale Normen. Frankfurt am Main: Suhrkamp Taschenbuch Verlag.

Robins, Steven L. 2009. From Revolution to Rights in South Africa: Social Movements, NGOs and Popular Politics After Apartheid. Pietermaritzburg: University of KwaZulu-Natal Press.

Saks, Michael J., and Peter David Blanck. 1992. 'Justice Improved: The Unrecognized Benefits of Aggregation and Sampling in the Trial of Mass Torts'. Stanford Law Review 44: 815-51.

Scarry, Elaine. 1985. The Body in Pain: The Making and Unmaking of the World. Oxford: Oxford University Press.

Truth and Reconciliation Commission South Africa. 2003. Truth and Reconciliation Commission Final Report, Vol. 6-7. Cape Town: Juta \& Co.

Van Marle, Karin. 2008. 'Lives of Action, Thinking and Revolt: A Feminist Call for Politics and Becoming in Post-Apartheid South Africa'. In Post-Apartheid Fragments: Law, Politics and Critique, edited by Wessel Le Roux and Karin Van Marle, 34-58. Pretoria: University of South Africa Press.

Walker, Laurens, and John Monahan. 2002. Social Science in Law: Cases and Materials. 5th ed. Foundation Press. 